\title{
The Dinosaur Region in Tanganyika Territory.
}

\author{
By C. W. Hobley, C.M.G.
}

THE expedition despatched to Tanganyika Territory in I924 to explore the occurrence of dinosaur remains has recently attracted a considerable amount of public attention, for the fossil-bearing deposits are being successfully worked and a considerable amount of material is now on its way to the British Museum. It may, therefore, be of interest to describe the area in which the finds were made. From Kenya Colony southwards, through Tanganyika Territory to Portuguese East Africa, the framework of the eastern portion of the continent is composed of an extensive series of ancient metamorphic rocks, mainly gneisses and schists, and often intersected by pegmatite veins. In some parts these rocks stand out in a series of bold mountain ranges alternating with flat plains; in other parts the mountain ranges are only represented by isolated peaks and rocky kopjes called Inselberge by German geologists.

On the eastern flank of this old land surface a series of sedimentary rocks are found, varying in age from Permo-Carboniferous or Karroo up to Tertiary, and it is in this strip of country that the beds carrying dinosaur remains are found.

The Karroo beds need not detain our attention, for although of great general interest on account of their being the coal-bearing series of South Africa, they are poorly represented in this region, and dinosaurs had in those times not yet made their appearance on the scene.

South of the Rufiji river in Tanganyika Territory there is a large area widening out southwards towards the Rovuma. This is covered with a varied range of sedimentary rocks of Secondary age dating from the Upper Jurassic, and containing representations of the Wealden beds and the Cretaceous, and so on, up to some Tertiary deposits the exact position of which is uncertain. The presence of these beds is evidence of a series of invasions of the sea alternated by periods of elevation and erosion. By great good fortune Nature has preserved for us in these beds the remains of some of the most curious and at the same time the biggest creatures which ever peopled this earth. There are three beds bearing saurian remains, the two lower being referred to the Upper Jurassic and the top one to the Wealden period. Information has recently also come to hand of the discovery of deposits in northern Nyasaland, which also carry saurian fossils, and although detailed information is scanty at present, it may mean that the habitat of these ancient monsters will be proved to be of much greater extent than was previously expected. Maybe these deposits formed a continuous sheet over this part of Africa before the Rift Valley subsidence in Tertiary times.

Why this region was so well suited for these creatures, and what the conditions were which enabled them to exist in such numbers, are very intriguing questions, the answer to which is not readily forthcoming; only lengthy and extensive research will afford data necessary for any definite opinion. So much for the past, and some will ask what the country is like to-day. In physiographical terms, it is a dissected plateau having a maximum height of about 2500 feet, of which only comparatively few patches remain. To the east and north-east it slopes gradually coastwards, and on the west side it descends abruptly to the old metamorphic floor. The principal areas of more elevated country which indicate the former land surface are the Makonde, Rondo, Mbwala, and Ngarama plateaux.

In the neighbourhood of the river valleys cliffs are sometimes seen, due to the unequal erosion of beds of varying hardness, and we thus get forms which remind one of the butte or mesa of North America.

One of the latest phases of earth movement in this part of Africa was a depression, for the mouths of the rivers are submerged valleys. Permanent water is found in the main rivers, but in the network of tributaries, which help to determine the topography, the supply of water is exiguous; the rocks are generally very porous, the torrential but short spring rains produce a temporary rush of water, which rapidly soaks away during the ensuing long dry season, leaving only a few brackish pools to form breeding places for myriads of mosquitoes.

It is a depressing country to travel through, or to work in ; for it is covered from end to end with the monotonous and typical bush which mantles so many thousands of square miles in eastern Africa. This bush country is here locally known as the pori, farther north it is called the nyika, and it is composed of an assemblage of acacias and wait-a-bits, interspersed with various kinds of xerophytic shrubs, with aloes, sansevieria, and euphorbias, encephelartos (a zamia), and that characteristic African monstrosity, the baobab. It is not uniformly dense; in fact, there are large stretches of country of an orchard-like character and carrying a rank growth of grass among the trees, and in such places a certain amount of game may be seen. The course of the rivers is often marked by a belt of fine trees, mimusops and such like, also phœnix palms.

The plant assemblage is a reflection of the meteorological conditions, for once we leave the actual coastline the rainfall becomes steadily less. The rainfall at Lindi is 32.7 inches; twenty miles inland it would probably be about half the amount, and the bulk of it will fall within about a couple of months or so. All along the east coast the small extent to which the monsoon rains affect the zone of the country for about 200 miles inland is a remarkable phenomenon. The moisture-bearing clouds do travel inland, but the hot air rising from the great belt of bush country appears to inhibit precipitation except where the clouds strike a mountain range; the cooler mass then causes some of the moisture to fall thereon, but the bulk sweeps on until it strikes some high plateau far inland.

As might be expected, such rigorous natural conditions have not made for great human progress or dense associations of human beings. A heterogeneous collection of people is scattered about on the flanks of the river valleys and on the higher parts of the plateau. They are all what is known as Bantus, the principal tribes found in the area being the Wa-Mwera, WaMakonde, Wa-Yao and Wa-Ngindo, Wa-Ngoni and Wa-Makua.

The Angoni, as is well known, are representatives of the great northward migration of part of the Zulu race, 
which took place somewhere about $\mathrm{I}_{225}$; it did not reach this region, however, until considerably later, and did not lead to a very extensive settlement; the Yao have also come from the south-west during the last fifty to sixty years, not in mass, but as a peaceful penetration; they are a virile race, and their arrival is a desirable thing for this region.

These coastal lands have been the scene of raids and counter-raids from time immemorial. In medieval times they were swept by the irresistible Ma-Zimba, and later were ravaged by Arab slave traders from Zanzibar ; then came the German occupation, and in 1905-6 the people rashly took an active part in what is known as the Maji maji rebellion, which was ruthlessly crushed by the Germans, and it is said that some I20,000 natives perished. In the War the area was the scene of desperate fighting between the Germans and the British expeditionary force, all peaceful development being necessarily suspended for the period of this struggle. The Tanganyika administration is, however, now endeavouring to improve the economic condition, but it is a slow and tedious work.

The women of the Mwera, Makonde, and Makua tribes affect an extraordinary ornament called the pelele; the upper lip is pierced, the hole is gradually enlarged, and eventually a wooden disc, often as much as two inches in diameter, is inserted and worn. In addition, the lower lip is sometimes pierced and a peg or pin of bone or iron is suspended from it. The origin of this curious custom is not certain, but the coast people assert that it is of recent origin and was done to prevent the women being carried off by the slave traders ; for one so mutilated had little value in the slave market. If this explanation is correct, it is curious to find the practice persisting to the present day; this generation will, however, see it disappear. The Yaos never adopted it; their women, however, pierce the side of the nose and insert a stud of wood ornamented with inlaid specks of white metal and called the chipini.

Vigorous native communities can only develop where natural conditions are favourable, in an area of natural fertility and abundant water supply. In the whole of the wide strip of bush land behind the east coast of Africa, from Kenya Colony to Portuguese territory, the conditions are very rigorous. The soil is fertile, but the rainfall is exiguous, and the permanent water supplies are scanty; years of drought are more common than seasons of plenty. The people become to some extent seasonal migrants, and the development of large settled communities is impossible. How can they form large villages when in the dry season it may be necessary for the women of a village to make a journey of two hours to fetch water from a filthy water-hole for cooking and drinking purposes? Little wonder also that, when they are lucky enough to harvest a good crop, they convert too great a proportion into beer, have orgies to celebrate their good fortune, and fail to lay by enough for the inevitable shortage which will ensue. The unhealthiness of the country, moreover, cannot fail to have an unfavourable effect on their vitality, for they are perpetually exposed to the onslaught of the Anopheles mosquito; their huts are infected with Ornithodorus ticks; the bush is tsetseridden; and the stagnant water supplies infect them with intestinal parasites. Even leprosy is not uncommon. These natives are, however, no lower in natural intelligence than those of other portions of Africa, and, when taken out of their squalid surroundings and trained under European influence, they are proved to be capable of considerable mental development; in their homeland their environment weighs them down.

Such is the land in which these wonderful fossil remains occur, and it may be gathered that their detailed exploration is not an easy task or one which can be hurriedly carried out. During the rains the vegetation spreads with great exuberance; foliage appears with a rush, the growth of the grass and the tendrils of creepers being remarkably rapid. The mantle of vegetation is so dense that all prospecting work for new outcrops has to be suspended. In a month or two all this beautiful greenery withers, very soon the grass fires begin, and the scene is changed from one of beauty into a blackened waste. The shade temperature rises to more than $100^{\circ}$, the nights become hotter, so that only hardened, devoted men can maintain their working energy under such arduous conditions.

This picture of the conditions to be encountered is not intended to deter, but to demonstrate that the task of thoroughly investigating this momentous discovery is one which requires the careful organisation of a team of workers, well fed and well looked after, and if possible all anxieties regarding transport and supplies should be taken off the shoulders of the technical staff. In this way results of the utmost value will assuredly be obtained.

\title{
Sex-Determination.
}

\author{
By Dr. F. A. E. CRew.
}

$\mathrm{GEX}$ is the term used to define the differentiation of individuals for the production of dissimilar gametes-the ova and the sperm. A male is an individual efficiently equipped for the elaboration of functional spermatozoa and for the conveyance of these towards the site of fertilisation. A female is an individual equipped for the elaboration of functional ova, for the conveyance of these towards the site of fertilisation, and often also for the transit of the zygote - the fertilised egg-at some stage of its development to the exterior. Associated with these differences in the internal and external reproductive organs there are others in the general characterisation, the phenotype, by which male and female can be distinguished on inspection. Further, the sexes can be distinguished by differences in the chromosome constitution of the cells of which the individual is built up.

During the process of cell division, changes occur in the nucleus of the cell by which the contained chromatin material resolves itself into a certain number of filaments of definite shape, and these become progressively shorter to assume the form (in many cases) of stout rods - the chromosomes-which arrange themselves on the equator of the spindle. The number of chromosomes 